\title{
Assessment of Tomato (Solanum lycopersicum) Genotypes for Yield and Yield Contributing Characters and Hybrid Development
}

\author{
A. K. Chippy*, Beena Thomas and M. Amrutha Unni \\ College of Agriculture, Vellayani, Trivandrum, Kerala, India \\ *Corresponding author
}

Keywords

Tomato, Genotypes,

Evaluation,

Quantitative

characteristics,

ANOVA

\section{Article Info}

Accepted:

12 December 2020

Available Online:

10 January 2021
A study was conducted focusing on evaluation of 10 tomato genotypes and their hybrids with a check variety based on twelve quantitative characters. Among the parents Pusa Ruby was recorded high mean value for plant height $(118.44 \mathrm{~cm})$, fruit volume $(65.11$ $\left.\mathrm{cm}^{3}\right)$, fruit weight $(60.86 \mathrm{~g})$ and yield per plant $(1123.77 \mathrm{~g})$. Akshaya recorded high mean value for primary branches per plant $(7.11 \mathrm{~cm})$ and number of leaves per plant (72.67). Anagha was recorded highest mean value for number of flowering clusters per plant (7.56). Lowest mean value for days to $50 \%$ flowering (43.22) was shown by Kottayam local. Kuttichal local recorded high mean value for number of fruits per cluster (4.11), fruit length $(4.68 \mathrm{~cm})$ and fruit girth $(16.39 \mathrm{~cm})$. Vellayanivijay was recorded high number of fruits per plant (39.89). Among 21 hybrids L1T2 was recorded high mean value for plant height $(91.52 \mathrm{~cm})$, primary branches per plant $(9.78)$ and number of leaves per plant (123.33).Lowest mean value for days to $50 \%$ flowering (43.00) was shown by L1T3. L4T2 was recorded high mean value for number of flowering clusters per plant (9.67), number of fruits per cluster (6.67) and number of fruits per plant (42.56). L6T3 was recorded highest mean value for fruit length $(4.69 \mathrm{~cm})$ and fruit volume $\left(51.67 \mathrm{~cm}^{3}\right)$. L4T1 was recorded high mean value for yield per plant $(1633.72 \mathrm{~g})$ and fruit girth $(16.26 \mathrm{~cm})$. High mean value for fruit weight (69.84 g) was recorded by L6T2. All the genotypes differed significantly among themselves based on ANOVA for all the characters studied. Therefore, there is an ample scope for selection of promising genotypes.

\section{Introduction}

Tomato (Solanum lycopersicum L.) is one of the most important vegetable crop worldwide, because of its wider adaptability, high yielding potential and suitability for variety of uses in fresh as well as processed food industries and ranks second after potato in terms of global production and first in terms of yield (FAOSTAT, 2018). Tomato fruit for human health is reflected by its high consumption per capita, and the identification of tomato varieties that accumulate higher levels of primary and secondary metabolites in their fruit is a priority objective (Hou et al., 2020). The fruits are available year-round and eaten raw or cooked. In large quantities is used to produce soup, juice, ketchup, puree, paste and powder; it supplies ascorbic acid and adds variety of colours and flavours to the food. 
Moreover, tomatoes are an integral part of the human diet being used fresh or cooked in pizza, ketchup, and tomato paste and provide important nutritional components such as carotenoids, vitamin C (ascorbic acid), phenols, and flavonoids. The carotenoid lycopene plays an especially important role for the consumer. Lycopene, which is highly abundant in tomatoes, is believed to provide health-promoting capabilities in the prevention and control of lung, breast, and prostate cancer.

Continuous inflow of exotic hybrid varieties and risk of getting appropriate variety at desired time created dilemma among the farmers while selecting suitable tomato varieties. Uncertainty in timely availability of hybrid seeds can be reduced by cultivation of suitable hybrid cultivar developed in the country (Shrestha and Sah, 2014). Development of hybrid tomato varieties having desirable characters has proven to be an effective strategy to increase tomato production (Islam et al., 2012). Therefore, research should be oriented towards tomato variety improvement through hybridization, selection, varietal evaluation and release of disease resistant, high yielding and consumer preferable hybrid varieties of tomato with high productivity. The present investigation was undertaken to study the performance of different tomato genotypes and their hybrids in terms of yield contributing characters.

\section{Materials and Methods}

The present investigation was carried out in the Department of plant breeding and Genetics, College of Agriculture, Vellayani, during 2017-2020. The experiment site is located at $8.5^{\circ}$ North latitude and $76.9^{\circ}$ East longitude, at an altitude of $29.00 \mathrm{~m}$ above mean sea level. Predominant soil type of the experimental site is red loam to Vellayani series, texturally classified as sandy clay loam. The area enjoys a warm humid tropical climate.

Hybrids are developed based on line $\mathrm{x}$ tester mating design. In tomato, anthesis occurs between 7 and 8 a.m. The well-developed flower buds which are expected to open next day morning were emasculated by the removal of anthers using forceps during evening hours and bagged using butter paper covers. On the next day morning (between 7 and 8 a.m.) emasculated flower buds were pollinated by the male parents (testers). The pollinated buds were again bagged with paper bags and labelled. The mature crossed fruits were harvested and the seeds were collected separately from each cross. For maintenance of parental genotypes, flower buds of parental genotypes were selfed by bagging the individual buds and properly tagged and later seeds were collected from the mature fruits.

The experimental material comprised of 10 genotypes collected from different sources (Table 1) and their hybrids and one check variety. The seedlings were raised in greenhouse in portrays and 30 days old seedlings of thirty two tomato genotypes were transplanted in field. The field was prepared to fine tilth by ploughing, harrowing, clod crushing and levelling. Plants were transplanted in main field at a spacing of 60 $\mathrm{cm} \times 60 \mathrm{~cm}$. The crop was managed as per the package of practices recommendation of Kerala Agricultural University (KAU, 2011).

The experiment was laid out in Randomized Block Design (RBD) with three replications.A total of 32 genotypes were raised in a plot with a spacing of $60 \times 60 \mathrm{~cm}$. Recommended agronomic practices and needbased plant protection measures were taken. Five plants were randomly selected in each treatment in each replication tagged and observations with respect to quantitative traits were recorded. 


\section{Results and Discussion}

\section{Analysis of variance}

The analysis of variance was carried out for all twelve characters studied. All the genotypes differed significantly among themselves for all the characters studied (Table 2). The treatment mean sum of square due to genotypes was found to be highly significant for all the characters studied which would ultimately indicate the diverse nature of selected genotypes. Therefore, there is an ample scope for selection of promising genotypes from the present gene pool for yield and its traits. The magnitude of variability among genotypes affected either by diverse nature of source of selected materials or by environmental influence over the phenotypic expression. These findings are in accordance with the findings of Basavaraj et al., (2010) and Dar and Sharma (2011).

\section{Mean performance}

The mean performance showed wide range of variation for most of the characters under study.

The plant height recorded the mean value of $93.52 \mathrm{~cm}$ for parents. Among the 10 parents, five genotypes had shown significantly higher values for the trait plant height based on mean value. plant height was the highest for Pusa ruby $(118.44 \mathrm{~cm})$.Least plant height was observed for Vellayanivijay $(72.62 \mathrm{~cm})$. The genotypes Akshaya, PKM 1, Arkameghali, Arkaalok and Pusa ruby shown significant mean values for plant height. Among the thirty two hybrids, eight hybrids had shown significantly higher values for the trait plant height based on mean value. plant height was the highest for L1T2 $(91.52 \mathrm{~cm})$. Least plant height was observed for L2T2 $(54.53 \mathrm{~cm})$. The hybrids L1T1, L1T3, L2T1, L3T3, L4T2, L6T1 and L6T2 shown significant mean values for plant height. The plant height of check variety (Arka Vikas) is more $(107.49 \mathrm{~cm})$ when compared to hybrids (Table 3). Sureshkumara et al., (2017) and Namitha et al., (2018) also reported differences in plant height among cultivars/hybrids of tomato put under evaluation and screening trials.

The mean performance of the trait number of primary branches per plant was 3.44 and range varied from 1.89 (Palakkad local) to 7.11 (Akshaya). Out of ten parents, two genotypes revealed significant for the trait number of primary branches per plant based on the mean value. Among the thirty two hybrids, mean performance of the trait number of primary branches per plant was 5.66 and range varied from 3.22 (L1T3) to 9.78 (L1T2). Eight genotypes revealed significant for the trait number of primary branches per plant based on the mean value. L1T2, L3T3 and L5T2 had shown more mean value than ArkaVikas. These results are in close conformity with the findings of Mohanti and Prusti(2001) who reported significant variation among the cultivars of tomato for the number of branches per plant.

Number of leaves per plant recorded the mean of 39.44 with the range of 23.11 (Kottayam local) to 72.67 (Akshaya) for the parents. Three genotypes had shown significantly high value for the trait. Among hybrids mean of number of leaves per plant was 51.54 with the range of 25.33 (L7T3)to 123.33 (LIT2) was recorded. Tenhybrids had shown significantly high value for the trait.

The mean obtained from the parents for the trait Days to $50 \%$ flowering was 47.76 with the range varied between 43.22 (Kottayam local) and 54.22 (VellayaniVijay). Among one ten parental genotypes, six genotypes had shown significantly low value for the trait Days to $50 \%$ flowering. Mean obtained from the hybrids for the trait Days to $50 \%$ 
flowering was 45.32 with the range varied between 43.00 (L1T3) and 49.67 (L2T3). Twelve hybrids had shown significantly low value for the trait Days to 50\% flowering. These findings were in accordance with Abrar et al., (2011) and Fayaz et al., (2007).

The mean obtained for the trait number of flowering clusters per plant was 6.66 which revealed significant in six parental genotypes. The trait number of flowering clusters per plant exhibited the minimum of 5.11 (Arkaalok) and the maximum 7.56 (Anagha) based on mean value. The mean obtained for hybrids for the trait number of flowering clusters per plant was 7.37 which revealed significant in ten hybrids. The trait number of flowering clusters per plant exhibited the minimum of 6.11 (L4T1) and the maximum 9.67 (L4T2) based on mean value. Seven hybrids had shown high mean value when compared to Arka Vikas.

The range recorded for number of fruits per cluster varied from 2.33 (ArkaAlok) to 4.67 (Anagha) with an average of 3.61 for parents. Four genotypes had shown significantly higher values for this trait based on mean value. The range recorded for number of fruits per cluster varied from 3.11 (L1T2, L4T1) to 6.67 (L4T2) with an average of 4.32 for hybrids. Ten genotypes had shown significantly higher values for this trait based on mean value. Two hybrids had shown high mean value when compare with check variety. The result concords with the finding of Sureshkumara et al., (2017) and Namitha et al., (2018).

Number of fruits per plant recorded the mean of 24.50 with the range of 16.11 (Palakkadu local) to 34.44 (Akshaya) for the parents. Three genotypes had shown significantly high value for the trait. Among hybrids mean of number of fruits per plant was 31.14 with the range of 20.56 (L6T1) to 42.56 (L4T2) was recorded. Ten hybrids had shown significantly high value for the trait.

The mean performance of the trait fruit length was $3.96 \mathrm{~cm}$ and range varied from $3.49 \mathrm{~cm}$ (ArkaMeghali) to 4.78 (PusaRuby). Out of ten parents, four genotypes revealed significant for the trait fruit length based on the mean value. Among the thirty two hybrids, mean performance of the trait fruit length was 3.94 and range varied from 3.51 (L5T1) to 4.69 (L6T3). Ten genotypes revealed significant for the trait fruit length based on the mean value. Fourteen hybrids had shown more mean value than Arkavikas. These results are in close conformity with the findings of Hozhbryan (2013) who reported significant variation among the cultivars of tomato for the fruit length.

Fruit girth recorded the mean of 12.78 with the range of 9.76 (Vellayani Vijay) to 10.48 (PusaRuby) for the parents. Four genotypes had shown significantly high value for the trait. Among hybrids mean of number of leaves per plant was 13.64 with the range of 9.32 (L1T3) to 16.26 (L4T1) was recorded. Four hybrids had shown significantly high value for the trait.

The mean obtained from the parents for the trait Fruit volume was $25.34 \mathrm{~cm}^{3}$ with the range varied between 10.22 (VellayaniVijay) and 65.11 (PusaRuby). Among one ten parental genotypes, three genotypes had shown significantly high value for the trait Fruit volume. Mean obtained from the hybrids for the trait Fruit volume was $36.37 \mathrm{~cm}^{3}$ with the range varied between $28.00 \mathrm{~cm}^{3}$ (L3T2) and 51.67 (L6T3). Twelve hybrids had shown significantly high value for the trait fruit volume. These findings were in accordance with Namitha et al., (2018).

Mean obtained for the trait fruit weight was $29.79 \mathrm{~g}$ which revealed significant in six 
parental genotypes. The trait fruit weight exhibited the minimum of $19.47 \mathrm{~g}$ (Vellayanivijay) and the maximum $60.86 \mathrm{~g}$ (Pusa ruby) based on mean value. The mean obtained for hybrids for the trait fruit weight was $42 \mathrm{~g}$ which revealed significant in ten hybrids. The trait fruit weight exhibited the minimum of $27.36 \mathrm{~g}$ (L2T2) and the maximum 69.84 (L6T2) based on mean value. Two hybrids had shown high mean value when compared to ArkaVikas. These results are in close conformity with the findings ofKaushik et al., (2011) who reported significant variation among the cultivars of tomato for the fruit length.

Fruit yield per plant recorded the mean of $683.11 \mathrm{~g}$ with the range of $300.83 \mathrm{~g}$ (ArkaAlok) to 1123.77 (PusaRuby) for the parents. Four genotypes had shown significantly high value for the trait. Among hybrids mean of yield per plant was 1268.69 with the range of 753.81 (L6T1) to 1633.72 (L4T1) as recorded. Twelve hybrids had shown significantly high value for the trait.
Yield per plant showed the greatest range of variation as reported by Haydar et al., (2007), Mehta and Asati (2008), Ghosh et al., (2010), and Kaushik et al., (2011).

\section{Analysis of variance}

The data were subjected for analysis of variance and it was found that the germplasm differed significantly for all nine characters studied. These findings are in accordance with the findings of Basavaraj et al., (2010) and Dar and Sharma (2011).

\section{Mean performance}

According to parents Akshaya, PKM 1, ArkaMeghali, ArkaAlok and PusaRuby shown significant mean values for plant height. The hybrids L1T1, L1T3, L2T1, L3T3, L4T2, L6T1 and L6T2 shown significant mean values for plant height. Sureshkumara et al., (2017) and Namitha et al., (2018) also reported differences in plant height among cultivars/hybrids.

Table.1 Details of the Tomato genotypes

\begin{tabular}{|c|c|c|}
\hline S1.no & Genotypes & Source of Collection \\
\hline L1 & Vellayani Vijay & KAU \\
\hline L2 & Anagha & KAU \\
\hline L3 & Akshaya & KAU \\
\hline L4 & PKM1 & TNAU \\
\hline L5 & ArkaMeghali & IIHR, Bengaluru \\
\hline L6 & Arka Alok & IIHR, Bengaluru \\
\hline L7 & Pusa Ruby & IARI, New Delhi \\
\hline T1 & Palakkadu Local & KAU \\
\hline T2 & Kuttichal Local & KAU \\
\hline T3 & Kottayam Local & KAU \\
\hline $\begin{array}{c}\text { Chec } \\
\text { k }\end{array}$ & Arka Vikas & IIHR, Bengaluru \\
\hline
\end{tabular}


Table.2 Analysis of variance of RBD for different characters in Tomato

\begin{tabular}{|c|c|c|c|c|c|c|c|c|c|c|c|c|c|}
\hline \multirow{2}{*}{$\begin{array}{l}\text { Source of } \\
\text { Variation }\end{array}$} & \multicolumn{13}{|c|}{ Mean sum of square } \\
\hline & d.f. & $\begin{array}{c}\text { Plant } \\
\text { height } \\
(\mathrm{cm})\end{array}$ & $\begin{array}{c}\text { Primary } \\
\text { branches } \\
\text { per plant } \\
\quad(\mathrm{cm})\end{array}$ & $\begin{array}{c}\text { No. of } \\
\text { leaves per } \\
\text { plant }\end{array}$ & $\begin{array}{c}\text { Days to } \\
50 \% \\
\text { flowering }\end{array}$ & $\begin{array}{c}\text { No. of } \\
\text { flowering } \\
\text { clusters } \\
\text { per plant }\end{array}$ & $\begin{array}{c}\text { Number } \\
\text { of fruits } \\
\text { per } \\
\text { cluster }\end{array}$ & $\begin{array}{c}\text { Number } \\
\text { of fruits } \\
\text { per plant }\end{array}$ & $\begin{array}{c}\text { Fruit } \\
\text { length } \\
\text { (cm) }\end{array}$ & $\begin{array}{l}\text { Fruit } \\
\text { girth } \\
(\mathrm{cm})\end{array}$ & $\begin{array}{c}\text { Fruit } \\
\text { volume } \\
\text { (cm3) }\end{array}$ & $\begin{array}{c}\text { Fruit } \\
\text { weight } \\
\text { (g) }\end{array}$ & $\begin{array}{l}\text { Yield per } \\
\text { plant (g) }\end{array}$ \\
\hline Replication & 2 & 14.03 & 6.27 & 19.56 & 7.98 & 2.651 .01 & 13.56 & 34.37 & 7.13 & 2.01 & 5.43 & 34.72 & 131.28 \\
\hline Genotype & 31 & $634.01 * *$ & $12.04 * *$ & $1310.66^{* *}$ & $24.87 * *$ & $2.09 * *$ & $2.26 * *$ & $150.76^{* *}$ & $0.40 * *$ & $9.66 * *$ & $461.20 * *$ & $397.65 * *$ & $424761.33^{* *}$ \\
\hline Error & 62 & 2.25 & 0.06 & 1.07 & 0.59 & 0.18 & 0.08 & 0.35 & 0.04 & 0.37 & 0.71 & 0.58 & 19.68 \\
\hline S.E. (d) & & 0.86 & 0.14 & 0.59 & 0.44 & 0.24 & 0.16 & 0.34 & 0.11 & 0.35 & 0.48 & 0.44 & 2.56 \\
\hline C.D. /lsd & & 2.45 & 0.40 & 1.68 & 1.26 & 0.70 & 0.47 & 0.97 & 0.33 & 0.99 & 1.37 & 1.25 & 7.24 \\
\hline
\end{tabular}

Table.3 Mean performance of Tomato genotypes

\begin{tabular}{|c|c|c|c|c|c|c|c|c|c|c|c|c|c|}
\hline S. No. & $\begin{array}{c}\text { Name of } \\
\text { genotypes }\end{array}$ & $\begin{array}{c}\text { Plant } \\
\text { height } \\
\text { (cm) }\end{array}$ & $\begin{array}{c}\text { Primary } \\
\text { branches } \\
\text { per plant } \\
(\mathrm{cm})\end{array}$ & $\begin{array}{c}\text { No. of } \\
\text { leaves } \\
\text { per } \\
\text { plant }\end{array}$ & $\begin{array}{c}\text { Days to } \\
50 \% \\
\text { flowering }\end{array}$ & $\begin{array}{c}\text { No. of } \\
\text { flowering } \\
\text { clusters } \\
\text { per plant }\end{array}$ & $\begin{array}{c}\text { Number } \\
\text { of fruits } \\
\text { per } \\
\text { cluster }\end{array}$ & $\begin{array}{c}\text { Number } \\
\text { of fruits } \\
\text { per } \\
\text { plant }\end{array}$ & $\begin{array}{c}\text { Fruit } \\
\text { length } \\
\text { (cm) }\end{array}$ & $\begin{array}{l}\text { Fruit } \\
\text { girth } \\
(\mathrm{cm})\end{array}$ & $\begin{array}{c}\text { Fruit } \\
\text { volume } \\
\text { (cm3) }\end{array}$ & $\begin{array}{c}\text { Fruit } \\
\text { weight } \\
\text { (g) }\end{array}$ & $\begin{array}{c}\text { Yield } \\
\text { per } \\
\text { plant }(\mathrm{g})\end{array}$ \\
\hline 1 & L1 & 72.62 & 2.67 & 25.11 & 54.22 & $7.56^{*}$ & $4.44^{*}$ & $39.89 *$ & 3.93 & 9.76 & 10.22 & 19.47 & $768.42 *$ \\
\hline 2 & L2 & 75.49 & 2.89 & 36.33 & $45.78 *$ & $7.56^{*}$ & $4.67 *$ & 22.11 & $3.51 *$ & 12.53 & 25.22 & $29.99 *$ & 645.97 \\
\hline 3 & L3 & $102.93 *$ & $7.11 *$ & $72.67 *$ & $44.22 *$ & 5.89 & 3.22 & $34.44^{*}$ & 3.86 & 12.21 & 20.44 & 25.00 & $887.23^{*}$ \\
\hline 4 & L4 & $99.58 *$ & $6.67 *$ & $57.78^{*}$ & $47.11 *$ & 6.56 & 3.44 & 19.22 & 3.71 & $13.23^{*}$ & $26.44^{*}$ & $31.86^{*}$ & 634.58 \\
\hline 5 & L5 & $115.23 *$ & 3.33 & $63.11^{*}$ & 52.00 & 6.11 & 3.33 & 24.33 & 3.49 & $13.21 *$ & $27.44^{*}$ & $37.44 *$ & $863.92 *$ \\
\hline 6 & L6 & $113.31 *$ & 2.22 & 32.33 & $44.56^{*}$ & 5.11 & 2.33 & 11.56 & 3.87 & 12.26 & 22.33 & 28.03 & 300.83 \\
\hline 7 & L7 & $118.44^{*}$ & 3.11 & 33.56 & 51.00 & $7.11 *$ & 3.44 & 18.67 & $4.78 *$ & $16.36^{*}$ & $65.11 *$ & $60.86^{*}$ & $1123.77^{*}$ \\
\hline 8 & $\mathrm{~T} 1$ & 74.47 & 1.89 & 24.00 & 50.22 & $6.67 *$ & 3.33 & 16.11 & 3.73 & 11.34 & 16.78 & 20.46 & 317.54 \\
\hline 9 & $\mathrm{~T} 2$ & 86.63 & 2.33 & 26.44 & $45.22 *$ & $7.11 *$ & $4.11 *$ & $28.22 *$ & $4.68 *$ & $16.39 *$ & 23.44 & 24.24 & 681.80 \\
\hline 10 & T3 & 76.52 & 2.22 & 23.11 & $43.22 *$ & $6.89 *$ & $3.78 *$ & $30.44 *$ & $4.04 *$ & 10.48 & 16.00 & 20.56 & 607.01 \\
\hline
\end{tabular}




\begin{tabular}{|c|c|c|c|c|c|c|c|c|c|c|c|c|c|}
\hline & Mean & 93.52 & 3.44 & 39.44 & 47.76 & 6.66 & 3.61 & 24.50 & 3.96 & 12.78 & 25.34 & 29.79 & 683.11 \\
\hline 11 & L1T1 & $79.37 *$ & 5.00 & 32.67 & $43.67 *$ & $7.56^{*}$ & $5.11 *$ & 31.11 & $4.16^{*}$ & 12.72 & 29.78 & $47.20 *$ & $1492.40 *$ \\
\hline 12 & L1T2 & $91.52 *$ & $9.78 *$ & $123.33 *$ & $44.33^{*}$ & 6.67 & 3.11 & 33.11 & 3.32 & 13.11 & 30.00 & 35.30 & 1139.15 \\
\hline 13 & L1T3 & $87.43^{*}$ & 3.22 & 42.89 & $43.00^{*}$ & $8.11 *$ & $4.78 *$ & $32.11^{*}$ & $4.41 *$ & 9.32 & 30.00 & 36.20 & 1117.43 \\
\hline 14 & L2T1 & $85.53 *$ & 5.22 & $75.22 *$ & 46.22 & $8.11 *$ & $4.78 *$ & 29.33 & 3.82 & $14.66^{*}$ & $43.00 *$ & $44.30 *$ & $1270.40 *$ \\
\hline 15 & L2T2 & 54.53 & $6.22 *$ & $52.44^{*}$ & $44.44^{*}$ & 6.78 & 3.44 & $35.44^{*}$ & $4.22 *$ & 12.60 & 28.11 & 27.36 & 917.13 \\
\hline 16 & L2T3 & 75.57 & 4.33 & 32.22 & 49.67 & 7.33 & 3.67 & 30.11 & $3.97 *$ & $13.69 *$ & $37.22 *$ & $45.83 *$ & $1356.93 *$ \\
\hline 17 & L3T1 & 77.51 & 3.22 & 43.89 & $44.00 *$ & $8.00 *$ & $4.89 *$ & $31.67^{*}$ & 3.58 & $13.93^{*}$ & $36.89 *$ & $43.33^{*}$ & 1173.12 \\
\hline 18 & L3T2 & 76.60 & $7.22 *$ & $56.22 *$ & $43.67 *$ & $8.00 *$ & $4.89 *$ & $32.22 *$ & 3.78 & 12.49 & 28.00 & 30.37 & 873.72 \\
\hline 19 & L3T3 & $87.44 *$ & $7.89 *$ & $68.11 *$ & $44.56^{*}$ & $8.11 *$ & $5.56^{*}$ & $40.11^{*}$ & 3.77 & 13.42 & 32.11 & 36.31 & $1423.01 *$ \\
\hline 20 & L4T1 & 85.43 & 4.78 & $52.33^{*}$ & $44.44^{*}$ & $6.11^{*}$ & 3.11 & $35.22 *$ & 3.80 & $16.26^{*}$ & $51.00^{*}$ & $48.95 *$ & $1633.72 *$ \\
\hline 21 & L4T2 & $89.62 *$ & $7.11 *$ & $76.22 *$ & $43.67 *$ & $9.67 *$ & $6.67 *$ & $42.56^{*}$ & $3.97 *$ & 14.28 & $36.67 *$ & 40.32 & $1633.66 *$ \\
\hline 22 & L4T3 & 75.49 & $5.78 *$ & 41.89 & 49.44 & 7.33 & $4.33 *$ & 27.22 & 3.82 & 13.39 & 30.00 & 36.39 & 970.73 \\
\hline 23 & L5T1 & 67.24 & 5.33 & 43.00 & 46.22 & 6.78 & 4.00 & $34.22 *$ & 3.51 & 13.14 & 31.78 & 41.65 & $1444.84 *$ \\
\hline 24 & L5T2 & 73.63 & $7.89 *$ & $55.56^{*}$ & $43.67 *$ & 7.00 & 4.11 & 30.44 & $4.30 *$ & $14.16^{*}$ & 36.11 & $44.36^{*}$ & $1307.39 *$ \\
\hline 25 & L5T3 & 76.54 & $6.67 *$ & $56.78 *$ & 46.00 & 7.11 & 4.11 & 25.00 & $4.56^{*}$ & $15.60 *$ & $50.11^{*}$ & $48.30 *$ & $1405.52 *$ \\
\hline 26 & L6T1 & $89.42 *$ & 4.78 & 44.44 & $43.67 *$ & 6.44 & 3.78 & 20.56 & $3.98 *$ & $14.09 *$ & $40.56^{*}$ & 38.32 & 753.81 \\
\hline 27 & L6T2 & $87.48^{*}$ & 4.89 & 40.33 & 46.22 & 6.89 & 3.22 & 21.67 & 3.81 & $14.49 *$ & $48.00 *$ & 69.84* & $1578.42 *$ \\
\hline 28 & L6T3 & 76.52 & 4.22 & 31.78 & 46.22 & $7.56^{*}$ & $4.44^{*}$ & $32.00 *$ & $4.69 *$ & $15.70^{*}$ & $51.67 *$ & $52.07 *$ & $1631.91 *$ \\
\hline 29 & L7T1 & 76.51 & 5.22 & $53.33^{*}$ & 49.33 & 6.56 & 3.78 & $34.44^{*}$ & 3.63 & 12.97 & 28.33 & 37.16 & 1239.46 \\
\hline 30 & L7T2 & 71.82 & 4.78 & 34.33 & $43.56^{*}$ & 7.00 & 4.22 & 25.44 & 3.59 & 13.09 & 28.89 & 36.70 & 993.60 \\
\hline \multirow[t]{2}{*}{31} & L7T3 & 77.70 & 5.33 & 25.33 & 45.67 & $7.56^{*}$ & $4.67 *$ & 30.00 & $3.99 *$ & 13.37 & 35.44 & 41.82 & $1286.13 *$ \\
\hline & Mean & 79.19 & 5.66 & 51.54 & 45.32 & 7.37 & 4.32 & 31.14 & 3.94 & 13.64 & 36.37 & 42.00 & 1268.69 \\
\hline Check & $\begin{array}{l}\text { Arka } \\
\text { Vikas }\end{array}$ & 107.49 & 7.67 & 66.11 & 44.22 & 7.56 & 5.11 & 30.33 & 3.83 & 16.64 & 58.33 & 50.78 & 1424.16 \\
\hline
\end{tabular}

*Significant at $5 \%$ level 
Out of ten parents, Akshaya and PKM 1 revealed significant for the trait number of primary branches per plant based on the mean value. Among the hybrids, L1T2, L3T3 and L5T2 had shown more mean value than ArkaVikas. These results are in close conformity with the findings of Mohanti and Prusti (2001).

Akshaya, PKM 1 and Arkameghali had shown significantly high value for the trait number of leaves per plant. Among hybrids, L1T2, L2T1, L2T2, L3T2, L3T3, L4T1, L4T2, L5T1, L5T2 and L7T1 had shown significantly high value for the trait. The result concords with the finding of Sureshkumara et al., (2017) and Namitha et al., (2018).

Among ten parental genotypes, L1T1, L1T2, L1T3，L2T2，L3T1，L3T2，L3T3，L4T1, L4T2, L5T2, L6T1 and L7T2 had shown significantly low value for the trait Days to $50 \%$ flowering.

Vellayanivijay, Anagha, Pusa ruby, Palakkadu local, Kuttichal local and Kottayam local had shown significantly high value for the trait number of flowering clusters per plant. Among the hybrids, L1T1, L1T3, L2T1, L3T1, L3T2, L3T3, L4T1, L4T2, L6T3 and L7T3 had shown significantly higher values.

Vellayanivijay, Anagha, Kuttichal local and Kottayam local revealed significant for the trait number of fruits per cluster based on the mean value. Among the hybrids, L1T3, L2T2, L3T1, L3T2, L3T3, L4T1, L4T2, L5T1, L6T3 and L7T1 had shown significantly higher values based on mean values. The result concords with the finding of Sureshkumara et al., (2017) and Namitha et al., (2018).

Vellaynivijay, Anagha, Kuttichal local and Kottayam local had shown significantly high value for the trait number of fruits per plant among parental genotypes. Among hybrids, L1T3, L2T2, L3T1, L3T2, L3T3, L4T1, L4T2, L5T1, L6T3 and L7T1 had shown significantly higher values than mean value. Turhan et al., (2011) and Abrar et al., (2011) also reported difference in number of fruits among different genotypes.

Out of ten parents, Anagha, Pusa ruby, Kuttichal local and Kottayam local revealed significant for the trait fruit length based on the mean value. Among hybrids L1T1, L1T3, L2T2, L2T3, L4T2, L5T2, L5T3, L6T1, L6T3 and L7T3revealed significant for the trait fruit length based on the mean value. Fourteen hybrids had shown more mean value than Arkavikas these results are in close conformity with the findings of Hozhbryan (2013) who reported significant variation among the cultivars of tomato for the fruit length.

In the case of fruit girth, PKM 1, Arkameghali, Pusa ruby and Kuttichal local had shown significantly high value. The hybrids L2T1, L2T3, L3T1, L4T1, L5T2, L5T3, L6T1, L6T2 and L6T3 had shown significantly high value for the trait.

Among one ten parental genotypes, PKM 1, Arkameghali and Pusa ruby had shown significantly high value for the trait Fruit volume. The hybrids L2T1, L2T3, L3T1, L4T1, L5T2 and L5T3 had shown significantly high value for the trait fruit volume. These findings were in accordance with Namitha et al., (2018).

Parental genotypes, Anagha, PKM 1, Arkameghali and Pusa ruby revealed significant in fruit weight based on the mean value. Hybrids L1T1, L2T1, L2T3, L3T1, L4T1, L5T2 and L5T3 had shown high mean value. These results are in close conformity with the findings of Kaushik et al., (2011) 
who reported significant variation among the cultivars of tomato for the fruit length.

Vellayanivijay, Akshaya, Arkameghali and Pusa ruby had shown significantly high value for yield per plant. Among hybrids L1T1, L2T1, L2T3, L3T3, L4T1, L4T2, L5T1, L5T2 and L5T3 had shown significantly high value for the trait. Yield per plant showed the greatest range of variation as reported by Haydar et al., (2007), Mehta and Asati (2008), Ghosh et al., (2010), and Kaushik et al., (2011).

Based on overall mean performance, the parental genotypes Vellayanivijay, Akshaya, Arkameghali, and Pusa ruby are suitable to improve the yield, and also other characters viz., fruit weight, number of fruits per plant and fruit volume. Therefore, these genotypes can be used in future breeding programme for improving the seed yield and other characters.

\section{Acknowledgement}

Authors are extremely grateful to the department of Plant Breeding and Genetics, College of Agriculture, Vellayani for making available plot of land for the Study. We are also highly indebted to the students and staff of the department for their unreserved support during the experimentation.

\section{References}

Abrar, H. S., Shams, U. M., Noor, U. A., \& Safdar, H. S. (2011). Evaluation of two nutrient solutions for growing tomatoes in a non-circulating hydroponics system. J. Agricul. 27(4): 558-567.

Basavaraj, N., Shashikanth., Hosamani, R. M., and Patil, B. C. 2010.Genetic variability in tomato (Solanum lycopersicon [Mill]. Wettsd.). Karnataka J. Agric. Sci. 23(3): 536-537. Dar, R.A. and Sharma, J.P. 2011. Genetic variability studies of yield and quality traits in tomato (Solanum lycopersicum L.). Int. J. Plant Breed. Genet. 5(2): 168- 174.

Dar, R.A. and Sharma, J.P. 2011. Genetic variability studies of yield and quality traits in tomato (Solanum lycopersicum L.). Int. J. Plant Breed. Genet. 5(2): 168- 174.

FAOSTAT.2018. UNFood and Agriculture Organization

statistics. http://www.fao.org/faostat/en.

Fayaz A., Khan, O., Sarwar, S., Hussain, A. and Sher, A. 2007. Performance Evaluation of Tomato Cultivars at High Altitude. Sarhad J. Agric. 23(3): 581585.

Ghosh, K.P., Islam, A.K.A., Mian, M.A.K., and Hossain, M.M. 2010.Variability and character association in F2 segregating population of different commercial hybrids of tomato (Solanum lycopersicum Mill). J. Appl. Sci. Environ. Manag. 14(2): 91- 95.

Haydar, A., Mandal, M. A., Ahmed, M. B., Hannan, M. M. and Karim, R. 2007.Studies on genetic variability and interrelationship among the different traits in tomato (Lycopersicon esculentum Mill.). J. Sci. Res. 2: 139142.

Hou, X., Zhang, W., Du, T., Kang, S. and Davies, W. J. 2020. Responses of water accumulation and solute metabolism in tomato fruit to water scarcity and implications for main fruit quality variables. J. Exp. Bot. 71: 1249-1264.

Hozhbryan, M. (2013). Effects of different levels of Urea on the growth and yield of tomato. JNAS J. 2:1031-1035.

Islam, M. R., Ahmad, S. and Rahman, M.M. 2012. Heterosis and qualitative attributes in winter tomato (Solanum lycopersicum L.) hybrids. Bangladesh J. Agric. Res. 37(1): 39-48.

Kaushik, S. K., Tomar, D. S., and Dixit, A. K. 
2011. Genetics of fruit yield and it's contributing characters in tomato (Solanum lycopersicon). J. Agri. Biot. Sustainable Development. 3(10):209 213.

Mehta, N. and Asati, B. S. 2008.Genetic relationship of growth and development traits with fruit yield in tomato (Lycopersicon esculentum Mill.). Karnataka J. Agric. Sci. 21: 92-96.

Mohanty, B.K. and Prusty. 2001. Evaluation of tomato varieties in black soils of western zone of Orissa. J. Trop. Agricul.39: 5-56.

Namitha, E., Beena, T and Thouseem, N. 2018. Evaluation of Tomato (Solanum lycopersicum L.) Genotypes under Water Stress Based on Yield and Physiological Parameters.
Int.J.Curr.Microbiol.App.Sci. $\quad 7(01)$ : 214-225.

Shrestha, S. L and Sah, R.L. 2014. Evaluation of Tomato Cultivars for Central Tarai of Nepal. Nepal J. Sci. and Technol. 15(2): 11-16.

Sureshkumara, B., Lingaiah, H.B., Shivapriya, M. and Pavithra, H.B. 2017. Evaluation of Tomato Genotypes for Growth, Yield and Quality Attributes Under Eastern Dry Zone of Karnataka, India. Int.J.Curr.Microbiol.App.Sci. 6(11): 1922-1930.

Turhan A., Ozmen N., Serbeci M.S., Seniz V. (2011): Effects of grafting on different rootstocks on tomato fruit yield and quality. Hort. Sci. (Prague), 38: 142149.

\section{How to cite this article:}

Chippy, Beena Thomas, A. K. and Amrutha Unni, M. 2021. Assessment of Tomato (Solanum lycopersicum) Genotypes for Yield and Yield Contributing Characters and Hybrid Development. Int.J.Curr.Microbiol.App.Sci. 10(01): 1599-1608. doi: https://doi.org/10.20546/ijcmas.2021.1001.186 